\title{
TINGKATAN PENGETAHUAN REMAJA PUTRI TENTANG PREMENSTENSION KELAS X
}

\author{
Ida Susila* \\ *Dosen Program Studi Diploma III Kebidanan Universitas Islam Lamongan \\ Jl. Veteran No 53 A Lamongan
}

\begin{abstract}
ABSTRAKS
Premenstension adalah kumpulan gejala fisik, psikologis dan emosi yang terkait dengan siklus menstruasi wanita. Survey awal yang dilakukan peneliti di SMP Negeri 2 Lamongan mulai tanggal 5 - 22 Pebruari 2016 dari 10 remaja putri di dapatkan data 8 orang $(80 \%)$ yang mengalami gejala premenstension dan 2 orang $(20 \%)$ yang tidak mengalami premenstension. Gejala-gejala tersebut dapat di perkirakan dan biasanya terjadi secara reguler pada 7-14 hari sebelum menstruasi. Mengetahui tingkatan pengetahuan tentang premenstension pada siswi kelas X di SMA Negeri 1 Lamongan

Desain penelitian yang digunakan adalah desain penelitian deskriptif populasi dalam penelitian ini adalah seluruh remaja putri kelas X di SMA Negeri 1 Lamongan sebanyak 40 responden sampel sebanyak 30 responden yang sesuai dengan kriteria inklusi diambil secara purposive sampling.

Hasil penelitian dapat dijelaskan bahwa responden yang mempunyai pengetahuan baik berjumlah 19 orang $(47,5)$, pengetahuan cukup berjumlah 16 orang (40), dan pengetahuan kurang berjumlah 5 orang $(12,5)$

Pengetahuan remaja putri tentang premenstension sebagian besar remaja putri mempunyai pengetahuan yang baik 24 orang $(60 \%)$.

Remaja putri hendaknya mampu meningkatkan kemampuan tentang premenstension dengan cara membaca buku serta informasi lain yang dapat menambah pengetahuan tentang premenstension, sehingga dapat mencega gejalagejala yang timbul.
\end{abstract}

Kata kunci : Pengetahuan, Premenstension.

\section{PENDAHULUAN}

Premenstension atau PMT merupakan kumpulan gejala fisik, psikologis, dan emosi yang terkait dengan siklus menstruasi wanita dan secara konsisten terjadi selama tahap luteal dari siklus menstruasi akibat perubahan hormonal yang berhubungan dengan siklus ovulasi (pelepasan sel telur dari ovarium) dan menstruasi. Premenstrual syndrome juga sering disebut tegangan premestension (PMT). Gejala-gejala tersebut dapat diperkirakan dan biasanya terjadi secara regular pada 7-14 hari sebelum menstruasi. (Saryono dan Waluyo S, 2009).

Dalam kehidupan sehari-hari seorang wanita, apabila akan menstruasi dapat mengalami beberapa gangguan seperti ketegangan prahaid/premenstrual tension(Mansjoer, 2001).

Sindrom itu akan hilang pada saat menstruasi dimulai sampai beberapa hari setelah selesai menstruasi. Hal ini paling umum mempengaruhi para remaja dan wanita-wanita didalam awal 
usia 20-50 tahun yaitu dimulai pada tahap pubertas dan berakhir pada tahap menopause. Selama masa reproduksi, sekitar $80-90 \%$ wanita yang mengalami menstruasi mendapat gejala seperti nyeri payudara, kembung, jerawat dan sembelit yang menandakan awal menstruasi. (Saryono dan Waluyo S, 2009).

Prevalensi terjadinya PMT menurut beberapa sumber menyatakan bahwa $80-90 \%$ wanita mengalami gejala psikologis ringan dan normal, hanya 5\% wanita menstruasi. Perkiraan untuk prevalensi PMT sejati adalah sekitar 5\% (Glasier, 2006). Sekitar $40 \%$ wanita berusia 14-50 tahun, menurut suatu penelitian, mengalami sindrom pra-menstruasi atau yang lebih dikenal dengan PMT (Premenstesion). Bahkan survai tahun 1982 di Amerika Serikat menunjukkan, PMT dialami $50 \%$ wanita dengan sosio-ekonomi menengah yang datang ke klinik ginekologi (Soeltra, 2007).

Berdasarkan data survey awal yang dilakukan peneliti di SMA Negeri 1 Lamongan mulai tanggal 15 sampai 22 Februari 2016 dari 10 remaja putri didapatkan data 8 orang $(80 \%)$ yang mengalami gejala premenstension dan 2 orang $(20 \%)$ yang tidak mengalami gejala premenstension.

Faktor yang dapat menyebabkan terjadinya premenstension (PMT) secara pasti belum diketahui. Namun faktor-faktor yang mempengaruhi terjadinya PMT yaitu faktor hormonal, kimiawi genetik, psikologis. faktor gaya hidup, sosial, budaya, biologi dan pengetahuan. Faktor hormonal yakni terjadi ketidakseimbangan antara hormon estrogen dan progesterone berhubungan dengan PMT. (Saryono dan Waluyo S, 2009)

Salah satu upaya untuk mengatasi masalah tersebut maka dibutuhkan konsumsi gizi yang seimbang, mengurangi kafein dan natrium, latihan fisik atau olah raga serta suplemen vitamin B6 dan vitamin E (Dita Andita, 2010).

Disamping itu juga diperlukan peningkatan peran petugas kesehatan dalam memberikan penyuluhan atau konseling tentang menstruasi dan permasalahannya sehingga remaja mempunyai pengetahuan dan informasi yang cukup serta mengetahui secara dini apabila timbul keluhan dan mengambil tindakan untuk mengatasinya (Saryono dan Waluyo S, 2009)

\section{TUJUAN PENELITIAN}

Untuk mengetahui tingkatan pengetahuan tentang prementension pada siswi kelas X di SMA Negeri 1 Lamongan 2016".

\section{PEMBAHASAN}

Pada penelitian ini peneliti akan menguraikan hasil dan pembahasan penelitian yang telah dilaksanakan pada tanggal 28 Agustus 2016 di SMA Negeri 1 Lamongan. Hasil penelitian ini disajikan dalam bentuk tabel-tabel serta keterangan singkat dibawahnya untuk mempermudah pemahaman isi dari penelitian ini.

Pada penyajian data dimulai dari hasil penelitian berupa gambaran umum sekolah, data umum dan data khusus. Data umum yang disajikan tentang karakteristik remaja putri berupa umur. Sedangkan data khusus yang disajikan berupa distribusi pengetahuan remaja putri tentang personal hygiene saat menstruasi.

\section{Lokasi penelitian}

SMA Negeri 1 Lamongan adalah satu pendidikan yang berada di bawah naungan Departemen Pendidikan Nasional Kabupaten Lamongan yang terletak di JLn. 
Veteran Lamongan Kecamatan Lamongan Kabupaten Lamongan.

Secara luas SMA Negeri 1 Lamongan adalah $12,897 \mathrm{~m}^{2}$ yang terbagi menjadi :

Luas Bangunan : $6.343 \mathrm{~m}^{2}$

Luas tanpa Bangunan : $6.554 \mathrm{~m}^{2}$

Jumlah : $12.897 \mathrm{~m}^{2}$

Daerah ini mudah di jangkau dengan alat transportasi roda 2 maupun roda 4 karena kondisi jalan yang baik.

\section{Persiapan dan pelaksanaan penelitian}

a. Langkah-langkah persiapan dalam penelitian:

1. Melakukan pra survey di SMA Negeri 1 Lamongan

2. Menyusun usulan penelitian dan mengajukan penelitian

3. Memperbaiki usulan penelitian dan konsultasi mengenai kerangka kuisioner.

b. Langkah-langkah pelaksanaan dalam penelitian

1. Menyerahkan surat izin Kepada Kepala Sekolah SMA Negeri 1 Lamongan

2. Pada tanggal 28 Agustus 2016 dilaksanakan penelitian secara langsung kepada responden

3. Memproses dan menganalisis jawaban kuesioner yang terkumpul.

4. Menarik Kesimpulan

5. Menulis Laporan hasil Penelitian

\section{Hasil Penelitian}

Data Demografi

1. Jumlah Siswa

Jumlah seluruh siswa 1500 siswa, yang terdiri dari :

Kelas X

Siswa perempuan : 368 orang

2. Fasilitas

1) Jumlah ruang guru: 1 unit

2) Jumlah ruang tata usaha : 1 unit

3) Jumlah ruang kelas : 40 unit

4) Perpustakaan : 1 unit

5) Musholah : 1 unit
6) Lapangan voli : 1 unit

7) Lapanga basket : 1 unit

\section{Data Umum}

A. Karakteristik

Responden

Berdasarkan Umur

Jumlah responden dalam penelitian ini adalah 40 orang, distribusi responden menurut umur disajikan dalam bentuk tabel berikut:

Tabel 1.1. Distribusi umur remaja putri di SMA Negeri 1 Lamongan

\begin{tabular}{|c|c|c|c|}
\hline No. & $\begin{array}{c}\text { Umur } \\
\text { (tahun) }\end{array}$ & F & $\begin{array}{c}\text { Prosentase } \\
(\%)\end{array}$ \\
\hline 1. & 14 & 5 & $(12,5)$ \\
2. & 15 & 16 & $(40)$ \\
3. & 16 & 19 & $(47,5)$ \\
\hline & & & 100 \\
\hline
\end{tabular}

Sumber : Data primer, Agustus 2016.

Berdasarkan tabel 1.1 dapat dijelaskan hampir sebagian setengahnya atau hampir sebagian remaja putri berumur 16 tahun yaitu sebanyak 19 orang $(47,5 \%)$. Sedangkan umur remaja putri yang paling kecil berumur 14 tahun sebanyak 5 orang $(12,5 \%)$.

\section{Data Khusus}

Pada data khusus dalam penelitian ini disajikan distribusi responden berdasarkan pengetahuan remaja remaja putri tentang premenstasion.

Pengetahuan remaja putri tentang premenstasion saat menstruasi didapat dari 40 orang responden, distribusi responden berdasarkan pengetahuan remaja putri disajikan dalam tabel 1.2.

Tabel 1.2 Distribusi pengetahuan remaja putri tentang 
premenstension di SMA Negeri 1 Lamongan 2015.

\begin{tabular}{|c|c|c|c|}
\hline No & $\begin{array}{l}\text { Pengetahuan } \\
\text { remaja putri }\end{array}$ & $\mathrm{F}$ & $\begin{array}{c}\text { Prosenta } \\
\text { se }(\%)\end{array}$ \\
\hline 1. & Baik & 24 & $60 \%$ \\
\hline 2. & Cukup & 14 & $35 \%$ \\
\hline 3. & Kurang & 2 & $5 \%$ \\
\hline \multicolumn{2}{|r|}{ Jumlah } & 40 & $100 \%$ \\
\hline
\end{tabular}

Sumber: Data Primer, Agustus 2016.

Berdasarkan tabel di atas dapat dijelaskan bahwa sebagian besar responden mempunyai pengetahuan baik yaitu berjumlah 24 orang $(60 \%)$.

\section{PEMBAHASAN}

Pada bagian ini peneliti membahas karakteristik responden (umur) dan tingkatan pengetahuan remaja putri tentang premenstension kelas $\mathrm{X}$ di SMA Negeri 1 Lamongan 2015.

\section{Karakteristik Responden}

a. Umur

Berdasarkan tabel 1.1. dapat dijelaskan bahwa dari 40 responden sebagian berumur 16 tahun yaitu sebanyak 19 orang $(47,5 \%)$.

Terdapat 3 fase remaja yaitu :

Hal ini menunjukkan bahwa sebagian besar responden adalah termasuk fase remaja akhir. Dimana pada umur ini, remaja putri sudah baik dalam mengaplikasikan personal hygiene saat menstruasi.

b. Tingkatan Pengetahuan

Berdasarkan tabel 1.2. dapat diketahui bahwa dari 40 responden sebagian besar responden mempunyai pengetahuan baik yaitu sebanyak 24 orang $(60 \%)$.

Menurut Notoatmodjo S (2003:03) bahwa pengetahuan merupakan domain yang sangat penting untuk terbentuknya tindakan seseorang karena dari penelitian ternyata perilaku yang didasari pengetahuan lebih langgeng dari pada perilaku yang tidak didasari oleh pengetahuan. Pengetahuan diperoleh dari pengalaman dan berbagai macam sumber, misalnya media masa, media elektronik dan lain sebagainya.

Pendapat tersebut sesuai dengan hasil penelitian yang dilakukan di SMA Negeri 1 Lamongan bahwa sebagian besar responden mempunyai pengetahuan cukup. Hal ini menunjukkan bahwa responden cukup memperoleh informasi dari berbagai sumber, diantaranya media masa dan media elektronik.

Pengetahuan dapat dipengaruhi oleh beberapa faktor, diantaranya yaitu umur. Dibawah ini akan dibahas mengenai gambaran pengetahuan remaja putri tentang personal hygiene saat menstruasi berdasarkan umur.

Berdasarkan hasil penelitian yang dapat dilihat pada lampiran 9, dapat ditemukan bahwa sebagian besar responden yang mempunyai pengetahuan cukup terdapat pada umur 15 tahun $(37,5 \%)$.

Menurut Hunlock (1998) yang dikutip oleh Nursalam dan Pariani S (2001:134) semakin cukup umur, tingkat kematangan dan kekuatan seseorang akan lebih matang dalam berpikir dan bekerja. Dari segi kepercayaan masyarakat, seseorang yang lebih dewasa akan lebih dipercaya dari orang yang belum cukup dewasa.

Dalam penelitian ini, teori diatas sesuai dengan hasil penelitian di SMA Negeri 1 Lamongan bahwa sebagian besar responden yang berusia 15 tahun mempunyai pengetahuan cukup karena pada usia tersebut responden belum cukup dewasa dalam berpikir sehingga dalam menerima informasi tidak dapat dipahami sepenuhnya. 


\section{Keterbatasan Penelitian}

Dalam melakukan penelitian ini masih banyak keterbatasan baik yang berasal dari peneliti maupun yang dikarenakan oleh hal lain seperti keterbatasan waktu penelitian, keterbatasan tersebut diantarannya:

a. Sampel, yang digunakan sangat terbatas hanya menggambarkan pengetahuan saja sehingga hasilnya kurang digenerasikan.

b. Instrumen. Kuesioner sebagai alat ukur atau alat pengambilan data tidak dilakukan uji validitas realibitas terlebih dahulu sehingga hasilnya belum bisa valid.

c. Literatur. Buku yang digunakan acuan dan penelitian ini kurang memadai sehingga penelitian masih banyak memerlukan penyempurnaan

\section{PENUTUP}

\section{Kesimpulan}

penelitian

merupakan jawaban yng diperoleh hal yang dipertanyakan pada penelitian, ini berarti tujuan peneliti telah tercapai.

Pengetahuan remaja putri (umur) sebagaian berusia 15-16 tahun yaitu 23 orang $(57,5 \%)$

\section{DAFTAR PUSTAKA}

A. Aziz Alimul Hidayat, (2007), Metode Penelitian Keperawatandan Teknik Analisis Data, Jakarta : Salemba Medika.

Andira, Dita. (2010). Seluk Beluk Kesehatan Reproduksi Wanita. Yogyakarta : A Plus Books.

Bubak, (2005), Buku Ajaran Keperawatan Maternitas, Jakarta: EGC.
Glasier A, \& Gebbie A, 2006, Keluarga Berencana dan Kesehatan Reproduksi, Jakarta: EGC

Mansjoer, Arif, dkk. 2008. "Kapita Selekta Kedokteran, Jakarta: Media Aesculapius

Notoatmodjo, Soekidjo. 2003. Pendidikan Dan Perilaku Kesehatan. Rineka Cipta. Jakarta.

Nursalam, (2008), Konsep Dan Penerapan Metodolog Penelitian Ilmu Keperawatan, Jakarta : Salemba Medika

Saryono dan Waluyo S, (2009), Sndrom Premenstuas, Yogyakarta : Nuha Medika

Soekidjo Notoatmo, (2005), Metode Penelitan Kesehatan, Jakarta : Rineka Cipta

Suharsimi Arikunto, (2006), Metode Penelitian Kesehatan, Jakarta: EGC 